\title{
Desert Nitrogen Cycles: Fecal Nitrogen From a Population of the Sahelian Tree Locust in Oman
}

\author{
Michael D. Robinson
}

Department of Biology, College of Science, Sultan Qaboos University, P.O. Box 36, Al Khod 123, Muscat, Sultanate of Oman.
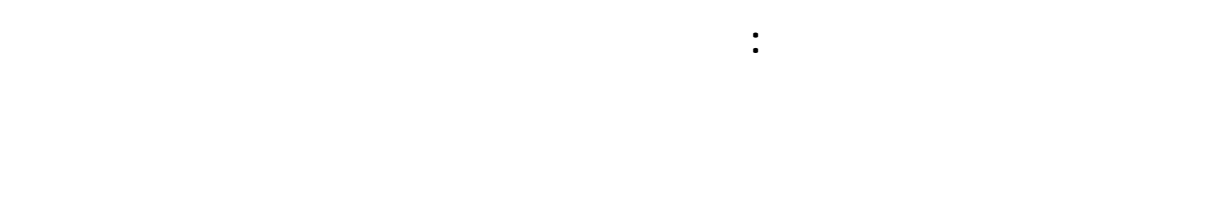

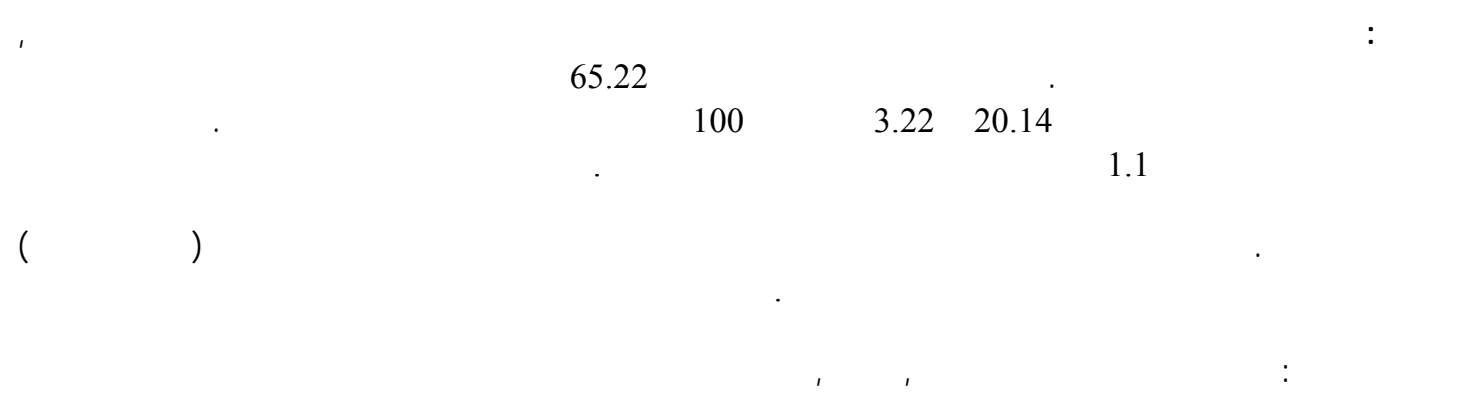

ABSTRACT: This research quantifies the amount of nitrogen deposited by the tree locust, Anacridium melanorhodon, during an irregular population outbreak in an Acacia tortilis woodland in Oman. The average standing crop of feces was $65.28 \mathrm{~g} \mathrm{~m}^{-2}$. The mean fecal crude protein and nitrogen were respectively, 20.14 and $3.22 \mathrm{~g} / 100 \mathrm{~g}$ ash-free dry weight. A hectare of this woodland would contain approximately $1.1 \mathrm{~kg}$ of fecal nitrogen beneath the trees. This single contribution by the locusts equals about one-third of the total standing crop of detrital nitrogen under perennial vegetation in a hectare of the Mohave Desert of North America. This, and the fact that grasshoppers are diverse and seasonally abundant in deserts, suggests they may be important organisms in nitrogen cycles.

KEYWORDS: Nitrogen Cycles; Fecal Nitrogen; Deserts; Tree Locust; Grasshoppers; Oman.

\section{Introduction}

Dhytophagous insects are important regulators of nutrient cycles in temperate forests (Mattson and Addy, 1975), but our knowledge of how they interact in desert ecosystems is still elementary. During the past two decades desert nutrient cycle research has focused on nitrogen, particularly on the concentration in plant tissues, leaf litter and soil (West and Skujins, 1978; Skujins, 1981; West, 1981; Whitford, 1986; Rundel and Gibson, 1996). Less attention has been given to the roles of animals in desert nitrogen cycles. Garner and Steinberger (1989) provide an insightful model of possible nitrogen pathways, and they emphasize that zoo-transport concentrates nitrogen around perennial vegetation. Field research by Dean et al. (1999) documents various ways vertebrate animals interact with trees in the arid woodland of the Kalahari Desert. It appears that the input of fecal nitrogen by tree locusts during one of their irregular population surges has not been quantified.

Tree locusts (genus Anacridium) are widely distributed in the arid and semi-arid regions of Africa and western Asia. During population outbreaks their swarms may cover several square kilometers and cause localized damage to trees (gum arabic, date and fruit trees) and other crops 


\section{MICHAEL ROBINSON}

(Popov and Ratcliffe, 1968; Marais and Wittneben1977; Showler, 1995); however, tree locusts are generally not a major pest. The Sahelian Tree Locust, Anacridium melanorhodon, is distributed in the Sahelian region of Africa (A. m. melanorhodon) and the coastal zone of the Arabian Peninsula (A. m. arabafrum). Normally, they roost and feed in native trees of the xeric woodlands ( eg., Acacia spp., Ziziphyus spp., Balanities aegyptiaca). A. m. arabafrum breeds erratically in response to winter and spring rains and may produce several generations in a year (Popov and Ratcliffe, 1968).

The objectives of this study were to estimate the amount of fecal nitrogen deposited by the Sahelian tree locust during a population outbreak, and to point out the potential importance of acridid orthopterans in desert nitrogen cycles.

\section{Methods}

The study site was located in the Sultanate of Oman, approximately $40 \mathrm{~km}$ west of Muscat and $3 \mathrm{~km}$ southeast of Sultan Qaboos University $\left(23^{\circ} 34.85^{\prime} \mathrm{N}, 58^{\circ} 11.14^{\prime} \mathrm{E}\right)$. Rainfall near the study area averages $81.3 \mathrm{~mm} /$ year (Fisher, 1994). The dominant perennial vegetation of this gravel plain includes Acacia tortilis, Lycium shawi, Acridocarpus orientalis, Jaubertia aucheri, Pulicaria glutinosa, and Tephrosia apollinea (nomenclature follows Ghazanfar, 1992). The locusts' primary roost was in samr trees (A. tortilis).

Adult tree locusts appeared on the study area sometime in late March 1998, and by April 2, approximately 10 to 30 individuals were seen in the larger trees. At the time of sampling (May 69), a clearly defined circular shadow of pellets was evident beneath most trees, representing the fecal accumulation of approximately 35-40 days. By May 25 the locust population was greatly reduced, but scattered individuals were still sighted in early autumn.

The standing crop of feces was quantified by collecting all fecal pellets inside four, $12.5 \mathrm{~cm}$ square quadrats that were placed randomly beneath the canopy of 16 trees, a total of 64 sample units. Anacridium feces were easily distinguished from other grasshopper species by their large size. The fecal pellets were of various ages and degrees of desiccation, which possibly affected their protein content. Eleven sample units had sufficient mass for the ash and crude protein analyses. These samples represented 8 different trees (Table 1). All the samples were cleaned and oven-dried $\left(60^{\circ} \mathrm{C}\right)$ to a constant mass. Crude protein was determined by the Kjeldahl method. The nitrogen content was assumed to be $16 \%$ of the crude protein (Cullison and Lowery, 1987). Samples were burned in a muffle furnace $\left(550^{\circ} \mathrm{C}\right)$ to determine the ash content.

Table 1: Ash, crude protein $(\mathrm{CP})$ and nitrogen $(\mathrm{N})$ in 11 samples of tree locust (Anacridium melanorhodon) feces. Values are g/100 g dry weight. Crude protein and nitrogen are corrected for mineral contamination (AFDW).

\begin{tabular}{|c|c|c|c|c|c|}
\hline Sample & Ash & CP & (AFDW) & Nitrogen & (AFDW) \\
\hline T1-4 & 9.53 & 20.24 & 22.37 & 3.24 & 3.56 \\
\hline T2-2 & 10.95 & 17.53 & 19.68 & 2.80 & 3.15 \\
\hline T2-3 & 10.28 & 16.59 & 18.49 & 2.65 & 2.96 \\
\hline T3-4 & 9.95 & 17.22 & 19.12 & 2.76 & 3.06 \\
\hline T4-1 & 11.03 & 17.36 & 19.52 & 2.78 & 3.12 \\
\hline T4-4 & 11.00 & 17.02 & 19.12 & 2.72 & 3.06 \\
\hline T9-3 & 11.76 & 19.01 & 21.54 & 3.04 & 3.45 \\
\hline T9-4 & 10.18 & 18.81 & 20.94 & 3.01 & 3.35 \\
\hline T15-1 & 10.11 & 18.45 & 20.52 & 2.96 & 3.28 \\
\hline T7-3 & 11.57 & 17.81 & 20.13 & 2.85 & 3.22 \\
\hline T5-2 & 11.61 & 17.80 & 20.14 & 2.85 & 3.22 \\
\hline
\end{tabular}




\section{LOCUST FECAL NITROGEN}

\section{Results}

The mean fecal dry weight biomass in a quadrat was $1.02 \mathrm{~g}$, or $65.28 \mathrm{~g} / \mathrm{m}^{2}$. Average density was 78.13 or 5000.32 pellets $/ \mathrm{m}^{2}$ (Table 2). This represents the fecal accumulation of slightly more than one month. The mean ( \pm one standard deviation) dry mass and length of the pellets was 12.7 $\mathrm{mg}( \pm 1.52)$ and $8.4 \mathrm{~mm}( \pm 1.36)$, respectively $(\mathrm{n}=30)$. The mean crude protein and nitrogen content of the feces was, respectively, $20.14( \pm 1.145)$ and $3.22( \pm 0.180) \mathrm{g} / 100 \mathrm{~g}$ ash-free dry weight (Table 1). Table 3 estimates the area beneath samr trees with various canopy diameters and the ash-free dry weight of feces, crude protein and nitrogen deposited by A. melanorhodon. One square meter would contain about $11.75 \mathrm{~g}$ of crude fecal protein and $1.88 \mathrm{~g}$ of fecal nitrogen.

Table 2: Mean dry weight biomass ( $\mathrm{g}$ ) and density of tree locust (Anacridium melanorhodon arabafrum, fecal pellets in $64,12.5 \mathrm{~cm}$ square quadrats beneath Acacia tortilis trees).

\begin{tabular}{|c|c|c|}
\hline & Biomass & Density \\
\hline Mean & 1.02 & 78.13 \\
\hline SD & 0.441 & 32.88 \\
\hline Minimum & 0.41 & 30.0 \\
\hline Maximum & 2.58 & 171.0 \\
\hline
\end{tabular}

Table 3 : Ash-free dry weight estimates of fecal mass, crude protein and nitrogen (g) deposited by Anacridium melanorhodon arabafrum in surface litter under Acacia tortilis trees of various canopy diameters.

\begin{tabular}{|c|c|c|c|c|}
\cline { 2 - 5 } \multicolumn{1}{c|}{} & \multicolumn{4}{|c|}{ Diameter (m) } \\
\cline { 2 - 5 } & 2 & 4 & 6 & 8 \\
\hline Area $\left(\mathrm{m}^{2}\right)$ & 3.14 & 12.57 & 28.27 & 50.27 \\
\hline Fecal Mass & 182.82 & 731.85 & 1645.93 & 2926.82 \\
\hline Crude protein & 36.82 & 147.42 & 331.54 & 589.55 \\
\hline Nitrogen & 5.90 & 23.58 & 53.05 & 934.33 \\
\hline
\end{tabular}

\section{Discussion}

Animal consumption and excretion are important pathways in nutrient cycles of desert and arid savanna (West, 1981; Garner and Steinberger,1989; Belsky et al. 1989). Grazing animals increase the amount of plant material returned to the soil and in particular the turnover rate of nitrogen. Mammalian feces decompose more rapidly than non-ingested plant material, accelerating the flow of materials. Vertebrate herbivores deposit dung while resting beneath trees (Dean et al. 1999). The feces of a Chihuahuan Desert jackrabbit (Lepus californicus) comprise $10 \%$ of the total litter mass beneath creosote shrubs and $13.8 \%$ in open areas (Whitford et al.,1982). Cowling (1977) estimates that $50-70 \%$ of the ingested nitrogen is returned as urine and a further $20 \%$ in dung.

While feeding, arthropods drop frass, partially eaten leaves, herbaceous stems and feces, into the surface litter, but estimates of this contribution by desert insect herbivores are very few. In a preliminary report, Boshoff (1988) estimates that immature Brown Locust (hoppers), at assumed swarm densities of 5000 individuals $/ \mathrm{m}^{2}$, could deposit $110 \mathrm{~kg}$ of frass/day. The average nitrogen concentration of the frass is $0.617 \mathrm{gN} / 100 \mathrm{~g}$ dry weight. At the roost sites $1 \mathrm{~m}^{2}$ would contain about 


\section{MICHAEL ROBINSON}

$0.093 \mathrm{gN}$. I assume his data are without ash corrections; no methods are given. Fecal nitrogen of adult tree locusts is 4.6 times more concentrated than the frass of the Brown Locust $(2.85 \mathrm{gN} /$ $100 \mathrm{gdw}$, not corrected for ash; Table 2). Locusts and other folivores capture nitrogen that would otherwise be translocated from the leaf prior to abscission. Nitrogen in tree locusts' feces is about $14 \%$ more concentrated than in the living leaflets of $A$. tortilis and $40 \%$ greater than the abscissed leaflets in the litter (M. Robinson, unpublished).

Some of the fecal nitrogen of acridids is derived endogenously from the peritrophic membrane, which surrounds the egesta. For example, the creosote bush grasshopper, Bootettix argentatus, invests $10 \%$ of the ingested protein in the peritrophic membrane. When fed a tanninrich diet, Anacridium melanorhodon produces a membrane that is $0.89 \%$ of the body weight (Bernays and Simpson, 1990). The main forms of fecal nitrogen excreted by Desert Locust (Schistocera gregaria) are uric acid (30-35\% of total egested nitrogen) and other undetermined nitrogenous waste products (55\%), such as ammonia, allantoin and allantoinic acid. The feces contain relatively little protein or free amino acids (Zanotto et al. 1993).

The time required to decompose tree locust feces and mineralize the nitrogen is unknown. Estimates of turnover times of desert litter vary widely from 14 years (Holmgren and Brewster, 1972) to around two years (Cormanor and Prusso, 1973). Binet (1981) concludes that feces decompose slowly and mineralized nitrogen could remain a long time. Most of the nitrogen returned via feces and urine is lost in the gaseous form, with only $1 \%$ of the nitrogen becoming incorporated into the soil (Rixon, 1970). O'Brien's research (1978) in the Chihuahuan Desert also suggests that most of the nitrogen is volatilized during mineralization.

Considering their species richness and great seasonal abundance, orthopterans are probably important components in desert nutrient cycles. Wisdom (1991) reports 10 genera and 13 species of grasshoppers (Acrididae) occur on the Sonoran Desert tree Prosopis glandulosa. Mohave Desert grasshoppers comprise as much as $8 \%$ of the total invertebrate biomass, and their bodies contribute $13 \mathrm{~g} \mathrm{~N} /$ ha to the nitrogen pool (Rundel and Gibson, 1996). Grasshoppers are also abundant in the deserts of western Asia and Africa. Popov (1980) reports 70 taxa from eastern Arabia. Locusts (Schistocerca, Locusta) are legendary for their phenomenal sporadic population surges and the economic loss they inflict on agriculture (Popov et al.,1984). However, the functional role of locusts and other acridids as concentrators of plant nitrogen and as a direct link to the decomposers has not been appreciated by ecologists.

The nitrogen budget of this community is unknown, but the potential input of fecal nitrogen by A. melanorhodon can be estimated. At a nearby site the density of $A$. tortilis averages 37 trees/ha. Most of these trees have canopy diameters between 3 and $6 \mathrm{~m}$ (Martin Fisher, personal communication). Assuming an average canopy diameter of $4.5 \mathrm{~m}$, then approximately $30 \mathrm{~g}$ of fecal nitrogen would have been deposited under each tree, or $1.1 \mathrm{~kg} / \mathrm{ha}$ (Table 3). Rundel and Gibson (1996) estimate that surface litter beneath perennial vegetation of the Mohave Desert contains $3 \mathrm{~kg}$ nitrogen/ha , only about two-thirds more than that contributed by tree locusts. Without knowing how much fecal nitrogen is mineralized and eventually becomes available to the plants, the true impact of these irregular nitrogen inputs is impossible to assess. Locusts cause great economic losses to crops, but they probably also benefit agricultural and natural ecosystems by the nitrogen they contribute through death and defecation. It remains for future research to more clearly define their role in desert nutrient cycles.

\section{Acknowledgements}

I thank Professor Neil Forsberg and Drs. Richard Early and Eugene Johnson of the Department of Animal and Veterinary Science, Sultan Qaboos University, and their technical staff, Kanthi Annamalai and Andrew Ritchie, for their collaboration in the analysis of samples. Drs. R. Chapman, S. Hanrahan, S. Green, C. Kooyman, and G. Sword provided useful advice and references. Sultan Qaboos University provided research facilities. 


\section{LOCUST FECAL NITROGEN}

\section{References}

BELSKY, A.J., AMUNDSON, R.G., DUXBURY, J.M., RIHA, S.J., ALI, A.R. and MWONGA, S.M. 1989. The effects of trees on their physical, chemical and biological environments in a semi-arid savanna in Kenya. Journal of Applied Ecology, 26: 1005-1024.

BERNAYS, E.A. and SIMPSON, S.J. 1990. Nutrition. In Biology of Grasshoppers. eds R.F. Chapman and A. Joern. John Wiley \& Sons, New York.

BINET, P. 1981. Short-term dynamics of minerals in arid ecosystems. In: Arid-Land-Ecosystems: Structure, Functioning and Management, Vol 2. eds D.W.Goodall and R.A. Perry. Cambridge University Press, Cambridge.

BOSHOFF, C. 1988. Does the Brown Locust play an important role in nutrient cycling? Proceedings Locust Symposium, MacGregor Museum, Kimberly, South Africa. South African Institute of Ecologists Bulletin Special Issue, 1988: 85-96.

CORMANOR, P.L and PRUSSO, D.C. 1973. Decomposition and mineralization in an Artemisia tridentata community in northern Nevada. U.S. IBP Desert Biome Research Memorandum, RM:73-79.

COWLING, S.W.1977. Effects of herbivores on nutrient cycling and distribution. In: Impact of Herbivores on Arid and Semi-arid Rangelands. Australian Rangeland Society, Perth.

CULLISON, A.E. and LOWERY, R.S. 1987. Feeds and Feeding ( $4^{\text {th }}$ Edn.). Prentice-Hall Inc., New Jersey.

DEAN, W.R.J., MILTON, S.J. and JELTSCH, F. 1999. Large trees, fertile islands, and birds in arid savanna. Journal of Arid Environments, 41: 61-78.

FISHER, M. 1994. Another look at the variability of desert climates, using examples from Oman. Global Ecology and Biogeography, 4: 79-87.

GARNER, W. and STEINBERGER, Y. 1989. A proposed mechanism for the formation of 'Fertile Islands' in the desert ecosystem. Journal of Arid Environments, 16: 257-262.

GHAZANFAR, S. 1992. An Annotated Catalogue of the Vascular Plants of Oman. Scripta Botanica Belgica 2. National Botanic Garden of Belgium, Meise.

HOLMGREN, R.C. and BREWSTER, S.F. Jr. 1972. Distribution of organic matter reserve in a desert shrub community. USDA Forest Service Research Paper INT-30.

MATTSON, W.J. and ADDY, N.D. 1975. Phytophagus insects as regulators of forest primary production. Science, 190: 515-522.

MARAIS, E. and WITTNEBEN, F. 1997. The 1994 outbreak of the Tree Locust Anacridium moestum in Namibia (Orthroptera: Acrididae: Cyrtacanthacridnae). Journal of the Namib Scientific Society, 45: 1-12.

O'BRIEN, R.T. 1978. Proteolysis and ammonification in desert soils. In: Nitrogen in Desert Ecosystems. eds N.E.West and J.Skujins. Dowden, Hutchinson and Ross, Stroudsberg.

POPOV, G. B. 1980. Acridoidea of eastern Arabia. Journal of Oman Studies Special Report No. 2: 113-148.

POPOV, G.B. and RATCLIFFE, M. 1968. The Sahelian tree locust, Anacridium melanorhodon. Anti-Locust Memoirs, 9: 1-45.

POPOV, G.B., WOOD, T.G. and HAGGIS, M. J. 1984. Insect pests of the Sahara. In: Sahara Desert, ed J.L. Cloudsley-Thompson. Pergamon Press, Oxford.

RIXON, A.J. 1970. Cycling of nutrients in a grazed Atriplex vesicaria community. In: The Biology of Atriplex. ed R.Jones. CSIRO Division of Plant Industry, Canberra.

RUNDEL, P.W. and GIBSON, A.C. 1996. Ecological Communities and Processes in a Mohave Desert Ecosystem: Rock Valley, Nevada. Cambridge University Press, Cambridge.

SHOWLER, A.T. 1995. Locust (Orthoptera:Acrididae) outbreak in Africa and Asia, 1992-1994: An overview. American Entomologist, 41: 179-185.

SKUJINS, J. 1981. Nitrogen cycling in arid ecosystems. In: Terrestrial Nitrogen Cycles: Processes, Ecosystem Stratigies, and Management Impacts. eds F.E. Clark and T. Rosswell, Ecological Bulletin (Stockholm), Stockholm. 


\section{MICHAEL ROBINSON}

WEST, N.E. 1981. Nutrient cycling in desert ecosystems. In: Arid-land Ecosystems: Structure, Functioning and Management. eds D.W. Goodall, R.A. Perry, and K.M.W. Howes, vol. 2, Cambridge University Press, Cambridge.

WEST, N. and SKUJINS, J. 1978. Nitrogen in Desert Ecosystems. Dowden, Hutchinson \& Ross, Stroudsberg.

WHITFORD, W.G. 1986. Decomposition and nutrient cycling in deserts. In: Pattern and Process in Desert Ecosystems. ed W.G.Whitford, University of New Mexico Press, Alburquerque.

WHITFORD, W.G., REPASS, R., PARKER, L.W. and ELKINS, N.Z. 1982. Effects of initial litter accumulation and climate on litter disappearance in a desert ecosystem. American Midland Naturalist, 108: 105-110.

WISDOM, C. S. 1991. Patterns of heterogeneity in desert herbivorous insect communities. In: The Ecology of Desert Organisms, ed G.A. Polis. University of Arizona Press, Tucson.

ZANNOTO, F.P., SIMPSON, S.J., and RAUBENHEIMER, D.1993. The regulation of growth by locusts through post-ingestive compensation for variation in the levels of dietary protein and carbohydrate. Physiological Entomology, 18: 425.434.

Received 14 November 2000

Accepted 19 May 2001 